\title{
POSTCOLONIAL LONGING ON THE AUSTRALIAN CINEMATIC FRONTIER
}

Pauline Marsh ${ }^{*}$

University of Tasmania

Tasmania, AU

\begin{abstract}
The Tracker and Red Hill are cinematic re-interpretations of Australia's colonial past, which they characterise by a sense of postcolonial longing and an expectation of intimacy. Both films are portals through which arguments about historical truth, subjective memory and contemporary realities are explored and tested. In this article I argue that both these two films create the idea that the historical colonial space was a constant interplay of violence and beauty, and of hatred and friendship. As black and white characters negotiate their way in and around these seemingly polemical positions, viewers are also challenged to do the same.
\end{abstract}

Keywords: Australian Film; Reconciliation Cinema; Colonial Australia; Aboriginal Representation; Australian Frontier Drama

In the frontier dramas The Tracker (2002, Dir. Rolf De Heer) and Red Hill (2010, Dir. Patrick Hughes) the Australian colony is fictively re-envisaged as a place of extreme violence, fuelled by bigotry and hatred. Far from being celebrations of colonial expansion, these Westerns are instead predominantly stories of disgraceful massacres and murders. Nonetheless, punctuating the destruction and lawlessness are moments of sensitivity and beauty, and depictions of gentle and understanding relationships between settlers and indigenous characters. Consequently The Tracker and Red Hill frontiers are nuanced spaces where meaningful, complex interactions between settlers and indigenes play out amid violence and racism. These contemporary re-visionings of Australia's frontier past indulge in a particular type of reflection that I term a postcolonial longing. The nostalgia in these films is not for triumphant colonial conquest and obliteration of Aborigines, but for friendships and understandings between non-indigenous and indigenous peoples.
Although stylistically diverse, common to both films is the use of narrative and stylistic tropes of the Western-horses, open landscapes, full moons and dramatic sunsets are shot in widescreen, and the disillusioned white hero is caught between the civilised and uncivilised. The Tracker, written and directed by Rolf De Heer and released in 2002, is set fairly late on the chronological timeline of the period of colonisation, 1922. However it takes place "[...] somewhere in Australia," in an outback area where British settlement is barely evident, which strongly evokes the "unexplored" and lawless frontier of an earlier time. It is the story of a group of three policemen and an Aboriginal tracker on the hunt for a fugitive at bay. On horseback, the men fruitlessly pursue an Aboriginal man who has been accused of murdering a white woman. The Tracker (David Gulpilil) physically leads the men in the search for The Fugitive (Noel Wilton) who remains, to the policemen's frustration, always a step ahead. Throughout the hunt the police

Dr Pauline Marsh is a researcher and teacher with the Centre for Rural Health. She has published in international journals in the areas of Aboriginal Studies, Film Theory and Palliative Care and is the director of her own short revisionist history film, The Conquest of Emmie (2016). Pauline has an established participant observation research relationship with a rural community garden in southern Tasmania and teaches into postgraduate primary health care units. Her email address is Pauline.Marsh@utas.edu.au 
taunt The Tracker and inflict gratuitous violence on the Aborigines they encounter during the search. The Tracker ultimately emerges from a guise of submission to avenge this white cruelty, and at the end of the film hangs the policeman in charge, The Fanatic (Gary Sweet). The complex nature of settler/indigenous relations is captured in The Tracker's relationship with both The Fanatic and the new young recruit, The Follower (Damon Gameau). The three men oscillate between respect, affection and overt hatred for each other. This interspersing of brutality with moments of gentle respect brings an unsettling intricacy to these frontier relations that bespeaks a longing for a truth of frontier history that can accommodate violence as well as camaraderie.

Red Hill (2010) is set not on the frontier, but in a highly stylised modern Australia. Nonetheless, it evokes the cinematic Western frontier at every opportunity: empty, wide streets; generic shop signs; men on horses; classic Western music; a wide and wild landscape; and a lawless town. Directed by Patrick Hughes, this film is a postmodern pastiche of modern characters and frontier mythologies. Constable Shane Cooper (Ryan Kwanten) has relocated to the small town of Red Hill that is, on his first day on the job, under siege from a disturbed and angry prison escapee Jimmy Conway (Tom E. Lewis). Conway is an Aboriginal man, once the finest brumby trackers in the area, who has been wrongly imprisoned. $\mathrm{He}$ is seeking revenge for past injustices inflicted on him by the police sergeant Old Bill (Steve Bisley) and the local men. Old Bill and his team of vigilantes close down the town in an attempt to kill Conway, but Conway systematically kills almost all of them, before being finally gunned down himself. Cooper makes a stand for Conway, and in doing so discovers the hidden truth about his past mistreatment by the police. In this film truth and fiction are interwoven to great extent. The story is, however, predominantly a classic morality tale of good versus evil, in which the corrupt are justly punished by the enlightened new generation of proreconciliation white police officers.

The Western has a long cinematic history that commenced in Hollywood but has been adopted and reinterpreted by other national cinemas, including
Australia's. Not classic Westerns, The Tracker and Red Hill are more appropriately described as "modern" or "revisionist," subcategories that refer to the socially critical Westerns that emerged in the 1950s and 1970s (Hayward 502). ${ }^{1}$ The revisionist Western is identifiable by its ability to redirect spectator sympathies "onto the displaced 'natives"' (MacFarlane, "Back Tracking” 62), and as such these films are also arguably postcolonial, as they explore the history of the settler-nation from points of view other than those of the colonisers. The Tracker and Red Hill also critique the politics, ideologies, power and race relations of colonisation and of its aftermath. By juxtaposing camaraderie against division, and beauty against horror, these works of fiction present contradictory frontier realities. These cinematic imaginings invite viewers to re-consider their own understandings of contact history, and of its relationship with contemporary ideas about reconciliation.

As works of historical fiction, these films add their particular stories to discussions about how history is and should be told, and stimulate debates of their own making about the relationships between truth, history and fiction. These are debates which permeate discourses of reconciliation. As Tom O'Regan states, a re-visionist history film challenges contemporary viewers to consider the state of contemporary crosscultural relations: "It problematises the 'pioneer legend', it disturbs the comfortable legitimacy of settler institutions and lifeways, and it necessitates reconciliation as a public project" (276). In this article a close reading of the narrative and stylistic elements of each of these films examines how a postcolonial longing for a complex past, which permeates these cinematic retellings of history, might engage with a reconciliatory future. The aesthetics of the two films-the music, poetry and cinematography-juxtaposing confronting violence, not only bespeak the desire for cross-cultural camaraderie, but also bring to attention connections between the past and the spectator's present. The present-day yearning for evidence of nuanced frontier intersubjectivities engages with many of the extratextual debates about the place of fictional imaginings of the past in contemporary understandings of reconciliation. 
In particular, these films contest the notion of a single and certain truth about the Australian frontier. Rather, they insist on multiple, discursively constructed and nuanced truths to explain the period.

\section{Slanting Truth in The Tracker}

On one level The Tracker imagines the frontier as a place of unchecked white racism and brutality toward Aboriginal people. The police consider themselves morally and intellectual superior to Aborigines and are quick to demonstrate their beliefs. During the journey the Tracker is placed in chains and made to walk in front of the horses while the others ride. The Fanatic frequently abuses, threatens and whips him and shoots at his feet. The Fanatic describes Aborigines as, "Cannibals, very treacherous", and a "repulsive breed" and he advises "you have to be firm with them" because, "they'll kill a white man in broad daylight." He is clear that his job involves the slaughter of Aborigines, as he explains to The Follower:

The Government employs me for a certain duty. They supply me with rifles, ammunition in abundance and they expect me to use it for the good of the country.

The campfire talk is about avoiding violent blacks, and the importance of being at the ready_ - watch your arses, watch your flanks." The viewer is left in no doubt as to the extent of the police racism following a scene in which a group of Aborigines are chained together, humiliated, tortured and shot. When the police initially approach the Aboriginal people, The Tracker fruitlessly tries to persuade The Fanatic that they are a peaceful group who are not involved in the Fugitive's escape. Ignoring The Tracker, and beneath Archie Roach's soundtrack in which he explains, "We are no longer free, [...] People of mine," The Fanatic and The Follower scream at the still, silent Aborigines while The Tracker, having claimed not to speak the same language, stands uncomfortably off to the side behind a tree. The Fanatic grabs a woman by the hair, strokes a man's face with his gun, pulls out the man's tongue, and as a close up of his face shows him smiling the music stops and is replaced by gunshots and screams. After the shootings they hang the people in the trees, as a warning to others, and ride away (figure 1).

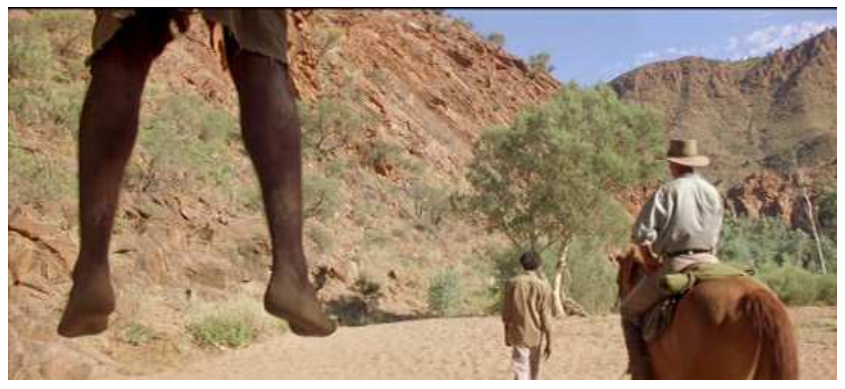

Fig. 1

Into this environment of friction and hostility The Tracker adds fleeting, contrasting images of camaraderie and understanding between the police party. Punctuating the racist taunting of The Tracker, for example, are moments when The Fanatic appreciates and trusts The Tracker's skills and shares his humour. For example, in the opening dialogue he asks The Tracker to let him know when it gets too dark to see the tracks. Later, he defends him against The Follower's accusations of dishonesty and fraud and makes The Follower dismount to learn how The Tracker reads the displacement of stones to follow tracks. The Fanatic also speaks a little of The Tracker's language, which demonstrates perhaps some willingness to communicate better, and because he does it quite poorly it has the effect of slightly weakening his arrogance. These brief displays of respect are reciprocated in kind by The Tracker who intermittently jokes along with The Fanatic. In one instance, The Tracker starts off the hunt at a playful trot, calling back over his shoulder to the mounted policemen "Like this? We catch him quick [...] Come on boss!" to which The Fanatic smirks, appreciating the joke. In another scene the two men laugh hysterically when The Tracker jests about Aboriginal people being "born for the noose" in reply to The Fanatic's suggestion that he will hang for insubordination. Both respond to The Tracker's attempt to establish some type of connection between the two men, through his self-deprecating humour. Neither The Fanatic nor the Tracker could be accused of being champions for reconciliation; however, their actions add 
a slightly unsettling complexity to both their bigotry and subordination that would otherwise dominate.

Toward the end of The Tracker cooperation between the two men all but dissipates as The Fanatic becomes unrelenting cruel. He chains The Tracker by the neck as he walks, and ties him to a tree to rest. For his part, The Tracker attempts unsuccessfully to drown The Fanatic. However, the camaraderie in the film then shifts to form another cross-cultural allegiance, this time between The Tracker and The Follower. The beginning point of this fragile alliance is the aftermath of the massacre, which has deeply disturbed The Follower (figure 2). The Tracker comforts him with a joke, reassuring him that "the only innocent black man is a dead man," and then encourages him to appreciate the irony that a black man should make such a remark. As the journey progresses, The Tracker begins to sympathise with The Follower, albeit quietly, when he becomes the target of The Fanatic's belittling. Eventually, The Follower betrays his boss in a single act of mutiny, provoked by The Fanatic shooting at Aborigines indiscriminately for a second time. The Follower then places The Fanatic in chains, intending to take him to trial for murder. Through this action the film implies ethics and principles of justice between The Tracker and The Follower. The sense of cross-cultural friendship in this film is, at best, slight. Indeed, considering the overpowering images of the scenes where Aborigines are slaughtered, it may only be the hint of camaraderie that the viewer may glimpse. Nevertheless, these moments are significant because they are also glimpses of cross-cultural understanding and dependency in what is otherwise a torrid frontier.

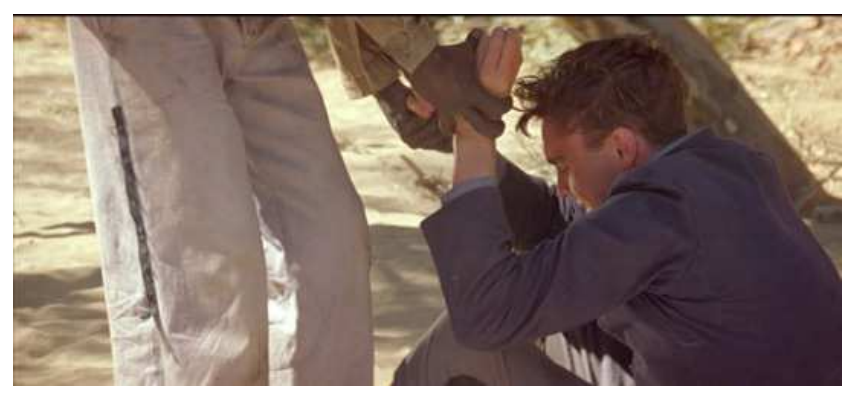

Fig. 2

It is not only in cinema that this desire for friendship and cooperation in the period of early contact history is evident. Philip Jones, for example, reads ethnographic objects from early colonisation as evidence of intercultural sharing and mutual dependence. Acknowledging firstly that encounters between Aborigines and settlers were frequently characterised by conflict, he then writes:

\begin{abstract}
Comprehending the historical moment of exchange, by which a net bag or boomerang was acquired for a plug of tobacco or metal knife, not only helps to reveal forgotten codes and protocols of remote frontiers, but also confirms that those frontiers were loaded with other possibilities, even with a tentative and provisional interdependence between black and white. (6)
\end{abstract}

Peter Sutton also documents what he calls the symbiotic relationships between some "unusual couples" of anthropologists and Aboriginal people. He considers these couples not, "as representatives of coloniser and colonised, male and female, or black and white, but as individuals whose experiences of each other were usually complex, may have at times been emotionally intense" (163-4). Similarly, historian Henry Reynolds has compiled evidence of settler-indigenous partnerships that took place amid periods of widespread colonial violence in his book This Whispering in our Hearts. The alliances in The Tracker are redolent of similar examples of interdependence documented in anthropology and history scholarship that responds to an "unease about the morality of settlement," which Reynolds suggests has "been apparent throughout the two centuries of European occupation of the Australian continent" (Whispering xiv). Also, when making the documentary television series The First Australians, Rachael Perkins was reportedly surprised to learn of the closeness and duration of inter-cultural friendships in the years following the arrival of the first white settlers (George 22).

The Tracker's attention to cinematic aesthetics augments the relationship complexity established in the narrative. Beautifully shot scenes, which are a delight to watch, contrast against harsh depictions of racism and brutality. For example, there are a number 
of long slow motion shots accompanied by unhurried and melodic music and lyrics by Archie Roach and lingering close-ups, which dwell on each character as they walk or ride in time to the music. Slow motion, close-ups and melodic song render actions as beautiful as they are terrifying. In one scene The Tracker attempts to drown The Fanatic by plunging himself off a cliff into a waterhole, while The Fanatic is chained to his wrist. It is a rhythmical, almost dance-like scene: a long pause within the chaos. As well, periodically throughout the film stills of paintings by artist Peter Coad are used as substitutes for depictions of physical violence (Fig. 3). Functioning partly as a distancing device, they also serve to add another element of visual artistry to the film, and thus add another level to the film's brutalitybeauty dialectic.

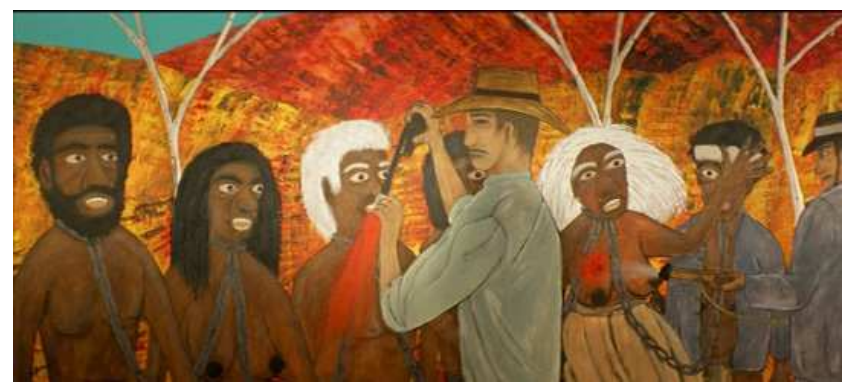

Fig. 3

An interplay between violent acts and lyrical verse in The Tracker has a similarly disconcerting effect. Murder accompanied by the recitation of poetry gives a nod to the beauty of language whilst committing an atrocity. For example, The Fanatic recites a Latin phrase after massacring the group of Aborigines: "Sic transit glorious mundi," (thus passes the glory of the world) and later, oblivious to his own imminent death recites two lines from a poem by Victorian poet Gerald Massey. David Shaw connects Massey's poem to the lyrical biblical book Song of Songs: "The world is full of beauty as are the worlds above/And if we do our duty, it might be full of love." As he completes this verse he is strung up to die and The Tracker, after calmly passing judgement on him for his murder of innocent people, repeats back to him the same Latin verse that The Fanatic has earlier recited after the massacre. On the one hand, the irony of speaking of love and glory during acts of torture and murder augments the wildness of this frontier. On the other, it demonstrates that those committing violence experience love and beauty and appreciate the significance of both. As a result, rather than widening the divide, this intermixing collapses conceptual boundaries between brutality and beauty.

These intersections of good and evil occur also at the level of the cinematic trope in The Tracker, in the figure of the Aboriginal tracker. The trope of the tracker embodies the paradoxes of colonial contact. A conflicted figure, he is at any given moment the "triumphant figure of culturally specific knowledge" and/or "part of an unwitting collusion in colonial expansion" (Probyn). He dwells somewhat uncomfortably in Homi Bhabha's interstices, between past, present, old and new, the postcolonial third space of the Australian frontier. The tormented tracker trope spans the life of Australian cinema. In Journey Out of Darkness (1967), a Tracker inter-textual referent film, non-Aboriginal and Aboriginal people distrust the Aboriginal tracker Jubbul (Ed Deveraux). Like in The Tracker, Jubbul is vital to the success of the hunt for a murderer-at-large, and yet the visiting policeman-in-charge belittles him repeatedly. Jubbul tries to do what he considers morally right by the Aboriginal community, but they curse him for his traitorousness and he dies. An extra-textual dimension compounds Jubbul's multiple identity battle, as in this case actor and character embody different racial identities-Ed Deveraux is non-Aboriginal and disguised in blackface to play the role. A more recent example, Moodoo (David Gulpilil), the tracker in Rabbit-Proof Fence (2002), is a similarly complex figure. $\mathrm{He}$ too is essential to the search, in this film not for a fugitive but to find three missing girls, but is afforded little respect and has a reputation amongst Aboriginal people for ruthlessness. Like DeHeer's Tracker, Moodoo treads a tenuous line between his Aboriginal and nonAboriginal allegiances. So too does Jacko (again played by cinema's quintessential tracker David Gulpilil) in The Proposition (2005). Jacko is subversive and attempts to protect Aborigines without police knowledge, yet he is considered a traitor by the Aboriginal outlaw Two-Bob.

It is de rigueur that contemporary trackers appear to be loyal to the police force whilst secretly 
outwitting their non-Aboriginal supervisors using cultural knowledge and intelligence. Marcia Langton describes The Tracker, as a "credible character with intent, intelligence, emotion, humour, and the strength and capacity to subvert the imperial mission" (59). In reconciliation cinema, these strong, complex figures perform a particularly important function. They provide the example of a historical black figure who is not the simple, passive victim of colonisation. They are deployed, therefore, to complicate simplistic ideals about a straight-forward brutality of the colonial frontier and to suggest a more complicated alternative. This may be a product of contemporary Australians feeling compelled to expunge their guilt over the past, as Jane Lydon suggests. She suspects The Tracker is a

vision of colonialism as many sympathetic viewers of our time would like to see it: the bad whites are punished, the well-meaning whites are educated about the power of Aboriginal culture, and the noble Aborigine is freed to return to his ancestral land. (140)

Indeed, trackers are at risk of being overromanticised, and used by filmmakers to downplay the racist tone of the nation's history. However, when the noble indigene also murders, betrays and is tormented by his internal tug-of-war of loyalties, alternative significations appear. The trope has the capacity to signal the possibility of less straightforward intersubjective encounters occurring on the frontier, and even of more intricate settler-indigenous relations.

Nevertheless, the white characters in The Tracker do not match the complexity of The Tracker, and at no point are the whites more obviously "bad whites" than in first massacre scene. The Follower is the only white character to be disturbed afterwards, but the others display a cool detachment. The callousness of the killings determines, as Lydon points out, that spectator sympathies lie firmly with the Aboriginal victims. The Tracker's response also firms the allegiance between the viewer and the Aborigines. He stands to the side, powerless and emotional, leaving the accompanying soundtrack lyrics to speak for him: "They're my people, my people, my people." The Tracker functions here as an empathetic conduit for the viewer. Robert Burgoyne observes that an emotional connection between the viewer and the history film can sometimes result in an awakening of "a probing sense of national self-scrutiny" (1). In this case, The Tracker speaks directly to national debates that periodically surface in Australian public discourses, and have done since the early 1990s, termed the "history wars." These self-scrutinising debates centre around how early colonial events should be interpreted and remembered.

The history wars ignited in 2000 after Keith Windschuttle claimed that along with other "fabrications" of history, "the mass killing of Aborigines was neither as widespread nor as common a feature of the expanding pastoral frontier in the nineteenth and early twentieth century as historians have claimed" (19). Responses and counter-responses by historians Henry Reynolds, Lyndall Ryan and others disputed the veracity of this and others of Windschuttle's claims, and all debated the relevance of the comments to contemporary indigenous realities. The debates extended beyond academia into broader political and cultural domains, and were essentially polemically divided along political ideology lines, between those on the neo-conservative right (denying the extent and frequency of massacres) and the progressive left (arguing for the recognition and acknowledgement of massacres). As Burgoyne warns, history films have a tendency to provoke controversy (1), and in December 2009 the debates resurfaced and this time engaged directly with Australian historical cinema. Extracts appeared in the national press of the third volume of Windschuttle's Fabrications of Aboriginal History outlining his accusations of the misrepresentation of truth in Phillip Noyce's Rabbit Proof Fence. This triggered defensive responses from the filmmakers (Owens 7) as well as the author of the book on which the film is based, Doris Pilkington (Perpitch 7). Questions arose about fiction's relationship with truth in general, and with the problems of retelling Australian history truthfully in particular.

At the core of the debates about feature film's role in telling history is the murky relationship between truth and fiction. Not dissimilar to the way that oral history has struggled to find a place in history annals, fictionalised 
accounts of historical events do not typically constitute conventional domains of Western historical records. There has been a long-running struggle for the feature films to be recognised for the legitimate contribution they make to historical inquiry. A notable voice in this struggle is that of Robert Rosenstone, who argues for film to be recognised alongside the conventional and established forms of written history and documentary. The argument for legitimacy, for film to be recognised as one "tool of production by which historical insights can be gained" (Berg 124), is a springboard for proponents who make the additional argument that history can only be fully understood through storytelling, fiction, and mythmaking. That is to say, fiction brings to light the shortcomings of conventional history methodologies. Referring to non-Western cultures and practices of oral history, Dipesh Chakrabarty, for example, explains: "there are voices from the other side which say 'Your methods are simply not good enough for my history. The methods by which you write history, those very methods, falsify my history"' (Attwood and Chakrabarty 201). Chakrabarty also uses the example of Tony Birch, Aboriginal poet, novelist and academic, who writes poetry in order to express more "accurate" versions of history than he could do otherwise (Attwood and Chakrabarty 202).

Anthropologist Basil Samson's work provides additional evidence to demonstrate the limitations of traditional, academic historical records. He documents different cultural conceptions of history between "traditional" Aborigines and non-Aboriginal people, and explains how Aboriginal "conventions that enjoin the editing of history" may result in the expunging of particular, unwelcome, elements of the past and replacement with new versions, one that are more consistent with the "formula," "always was always will be" (160). A similar discord was noted more recently by Australian and American historians who journeyed around the North of Australia in search of new ways of "doing" Aboriginal history, but discovered deep incongruities in the values and understandings of history between Aborigines and non-Aborigines (Hayward). These different cultural particularities highlight some of the constraints of conventional historical methods that fictional storytelling is well-placed to address.
Baudrillard celebrates the fact that although mythology is generally missing from the history annals, it can be present on-screen: "Myth, chased from the real by the violence of history, finds refuge in cinema" (43). Belinda Smaill also claims that cinema allows what is otherwise unrepresentable to become representable (32). The Tracker explores a range of possibilities of the past, through its inclusion of an "unrepresentable" intermix of violence and beauty, of frontier mythologies and of its depictions of settlers and indigenous people treatment of each other. This speaks to Tiziana FerreroRegis's claim that a function of Australian cinema is to address "contested stories related to the colonial treatment of Australian Aboriginal and Torres Strait Islanders" (104), that is, to use fiction to explore the various conflicting accounts of colonial history. The Tracker's position on truth, and that of cinematic historical dramas in general, is perhaps thus best understood using Naomi Jacobs eloquent explanation: "Fiction tells its truths slantwise" (195). The Tracker is neither the voice of frontier truth nor a work of fantastical whimsy. Its relationship with truth is more complicated. This film moves about in the interstices of these two extremes which renders the distinction between truth and fiction arbitrary. As a piece of Reconciliation Cinema it contributes to a collection of "truths" that constitute frontier history: objective and subjective accounts, history that is drawn from written records, oral history, memories and conversations.

Bain Attwood reminds us that the truths of the past are always constructed through its narration and re-telling. He states: "there is always a difference between what happened in the past and what was and is narrated later [...] history is not the past, but always the past represented and re-presented" ("Learning" 188). As such, historical films are re-presentations of already prior-mediated versions of events. The events are in turn re-organised and re-explained at the point of the spectator-screen encounter, and moreover, in the post-screening discussions that occur and the filmic discourse that develops around the film. This filmic manifestation of Jurgan Habermas discursive truth (35-38) rests on the idea that truth is determined not by a single voice, but by multiple negotiating voices. In 
film, this occurs on and off the screen in intersubjective encounters, and also in dialogue between spectators. Indeed, Natalie Zemon Davis suggests that all might be cast as participants in a collective "thought experiment" of the past (3). Reconciliation is a process that is ripe for discursively determined truths. The South African Truth and Reconciliation Commission (TRC), for instance, sought to establish "narrative", "social, or dialogue truth" (Kiss 74). Elizabeth Kiss explains that the Commission gave weight to stories and personal interpretations of events that occurred during the apartheid period, "in an effort to develop as complete a picture as possible of past injustices" (74) and with the overall aim of achieving reconciliation.

Another related, important consideration in reconciliation discourse in Australia is the relationship between the events of the past with present-day inequities between black and white Australians: the aftermath of colonisation. The effectiveness of reconciliation is commonly thought to be contingent on "coming to terms" with the past, exemplified in Aden Ridgeway's statement: "An Australian never challenged by reconciliation is one who never knows the truth of the past and will never know the meaning of the future" (17) (see also Maddison; and Clendinnen). Feature filmmakers have a long-held interest in the relationship between the past and the present also. Leger Grindon, for example, argues that

[f] rom the earliest days of their artistic practice, filmmakers have engaged in the centuriesold tradition of grappling with the present by writing about the past [...] a means by which the cinema associates past events with contemporary issues that it seeks to explain, justify, or exalt. (1)

Davis points also to the role that contemporary technical cinematic elements play in providing the means for historical speculation (5-7). Scholarly opinions differ on whether The Tracker effectively negotiates its way through contemporary issues as it revisits the past using contemporary narrative techniques. Felicity Collins and Therese Davis read the film as a direct comment on the present, through its exploration of an "ethics of friendship" and recognition of indigenous "custodial obligation and belonging" (14, 17, 16). Lydon, on the other hand, believes that "the films' otherworldly aspects [Coad's paintings, the lack of dialogue, the elegiac quality of Archie Roach's voice, the use of slow motion, and the archetypal characters] conspire to create a sense of myth, timelessness, universality" (139), and thus render it irrelevant to contemporary situations. She also contends that narrative closure effects a distancing of the present from the past: "When the lights come up the viewer returns to the 'real' world, leaving the filmic version very concretely behind" (141).

I suggest that one way that The Tracker does make a direct association between The Tracker's past and present-day realities is through the original soundtrack. Indigenous singer/songwriter Archie Roach is a conduit between the (cinematic) frontier and presentday settler-indigenous relations. Gary Gillard suggests Roach's songs are "arguably just as important to the intention of the film as if they were sung onscreen as Paul Kelly and Kelton Pell do in [One Night the Moon]" (118). The significance of the music to the film is indicated also by Archie Roach's live performance of the soundtrack at the film's premiere in Adelaide. Moreover, the soundtrack won an ARIA award for Best Original Soundtrack Album in 2002. The music works to establish a connection between past and present in two key ways. The first is through using the lyrics to verbalise the links. For example, towards the end of the film Roach sings:

\footnotetext{
You have taken my land and I can only return when there is contrition ...

I still long for my country, I still remember the spirit that was in my land,

But I can only forgive when there is contrition.

And we at last face my history.
}

Evoking rights-based and symbolic dimensions of reconciliation-forced dispossession, land rights and the call for a formal apology-the song is an overt statement of beliefs about the ongoing impacts of 
colonisation. Because it is Roach who makes this appeal to spectators, and not the historical figures in the film, this becomes another way the film brings the frontier into direct contact with the present.

Roach is a high-profile Aboriginal musician who tours widely and at the time of writing has released six albums. He is described as a "well-known stolen generations narrator" (Attwood, "Learning") and, along with his recently deceased partner Ruby Hunter, is said to have been a key contributor to the "public bank of popular and sought after Aboriginal history" (Attwood, Telling 51-53). Roach functions as an additional contemporary, living character in the film. His public persona as a member of the Stolen Generations situates the on-screen frontier violence, and friendships, in the context of more recent narratives of the treatment of Aborigines.

The Tracker creates the picture of a frontier constituted by an intricate meshing of characters, ethics, ideologies and behaviours. Red Hill develops this sense of complexity further, as the strong themes of violence and brutality are again punctuated by instances of kindness. And throughout, there is a sense of longing for a past that was not entirely dysfunctional.

\section{A New Generation of Righteous Avengers in Red Hill}

Red Hill's plot is one of a typical Western. One man, Jimmy Conway (figure 4), seeks revenge for atrocities committed against him and his family in the past. The hero, Cooper, is a clean-cut "cowboy" who has recently arrived in town. Unlike his new neighbours, Cooper has a strong sense of morality, truth and justice, and a cowboy belief that good will triumph over evil. Red Hill speaks back to classical pioneer legend through the inversion of the standard race binary: the white Red Hill townsfolk personify evil, whereas Cooper and the indigenous Conway are the representatives of all things good. In this film horrendous events of the past-unjust and seeped in racist ignorance-are countered by the actions of a handful of righteous, enlightened individuals who break the norm by being kind to each other.

The bulk of this film's 93 minutes is dedicated to Conway's systematic murdering of all the men who were responsible for his wrongful imprisonment that took place some years prior. The unrelenting nature of the violence in Red Hill draws comparisons with the films of the Coen Brothers, particularly No Country for Old Men in which a psychopathic killer murders with a ruthless disregard for his actions (e.g., French; Clarke; Elley; and Buckmaster). Conway has escaped from gaol and has headed straight to the town of Red Hill to extract revenge, "bringing hell with him," as predicted by Old Bill, the policeman in charge of Red Hill station. Not speaking, he simply shoots to torture and to kill. He displays the eerie calm of a cinematic psychopath throughout the film; eating dessert while his victims moan in near-death agony and ignoring the desperate pleas for clemency from frightened, cowering men concerned for their children. For the most part Conway kills with guns but, consistent with the overall temporal mishmash that constitutes this film, he also uses spears and even a boomerang toward the end.

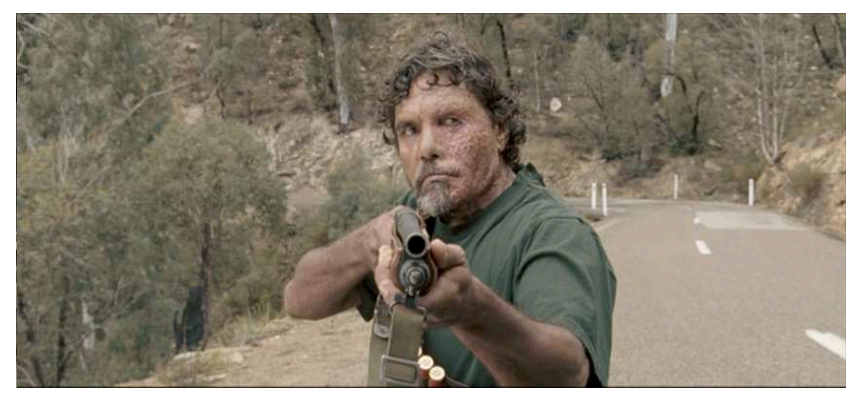

Fig. 4

Conway's capacity for violence is heightened by a strong intertextual connection between Red Hill and the 1978 Fred Schepisi historical feature film The Chant of Jimmy Blacksmith. Tom E. Lewis had his first acting role in The Chant, playing Jimmy Blacksmith, a young Aboriginal man who massacres the owners of the property where he lives with his wife. Lewis's careerstarting film is most memorable for the disturbing massacre scene, in which Blacksmith, assisted by his cousin Mort (Freddy Reynolds), hacks the women and children to death with an axe. Henry Reynolds states that audiences at the time were greatly confronted by the murders, particularly because they were committed by a black man against innocent whites, and that this was the cause for the film's box office failure and the 
lack of films about "racial issues" over the ensuing twenty years (The Chant 59). The similarities between Red Hill and The Chant are not only in the lead actors and the protagonist's first names. Both are also set on the Australian frontier; Blacksmith, like Conway, has a severely disfigured face caused by an injury inflicted by the police; and both killers are motivated by their experiences of racist mistreatment. The clear connections between Lewis's two Jimmys brings to the minds of those spectators who are familiar with The Chant the brutal violence of that film, and instils an expectation of a repeat performance by the next incarnation.

Conway's capacity for violence is equalled by that of the old-guard police and their team of vigilantes. The film establishes Old Bill as a man unafraid to shoot to kill early in the film, by constructing him in opposition to the pacifist Cooper. Cooper, on the morning of his first day, is not even able to find his gun, much less shoot it. In conversation with Old Bill it is revealed that in the past Cooper has chosen not to fire his gun, and then required counselling after being shot himself by the "strung-out kid" whom he spared. Old Bill is incredulous and judgemental: "You couldn't pull the trigger? ... A kid, with a gun." When Cooper protests, "Maybe he needed help, not a bullet", Old Bill dismisses this with practical logic: "We would be having a different conversation if you were dead." For Old Bill shooting is a practical necessity of police work. When he hears Conway has escaped, he assembles a team of vigilantes who are heavily armed and on a mission to kill. Old Bill instructs: "No one leaves this room without a weapon ... Shoot to kill." The violence is clearly racially motivated, as the target is Conway, the "black bastard."

Foremost of the counterbalancing elements in this film, that collectively soften the impact of the violence, is a gentle, loving relationship between Cooper and his heavily pregnant and physically vulnerable wife (Claire Van Der Boom). The couple have moved to the country so she can manage her blood pressure, having miscarried with their first baby. Cooper's sensitivity to his wife signals his capacity to caring and kind, which equips him to approach Conway with a believable spirit of understanding, rather than fear and hatred that permeates the town. Red Hill also interrupts the violence formatively, by way of stylised homage to the classic Western. Widescreen shots of the empty, still landscape celebrate the beauty of the Australian outback. Moreover, most of the horror takes place at night during a storm, which means the shots of the day are left, for the most part, peaceful. A passive old horse, Bess (figure 5), lives in the front yard of the Police station, conjuring a quiet ideal of "one horse town." The use of twangy, country music by Charlie Parr adds a quaint, unthreatening atmosphere, and complements the comic-book style depiction of the town. The shops are almost two-dimensional and devoid of advertising, and their minimalist signs such as "Barber Shop", "Golden Age Motel", "Butcher" and "Cafe" evoke an oldworld romanticism. In comparison to the dominating violence of the film these peaceful elements are minor, but have an undermining effect nonetheless.

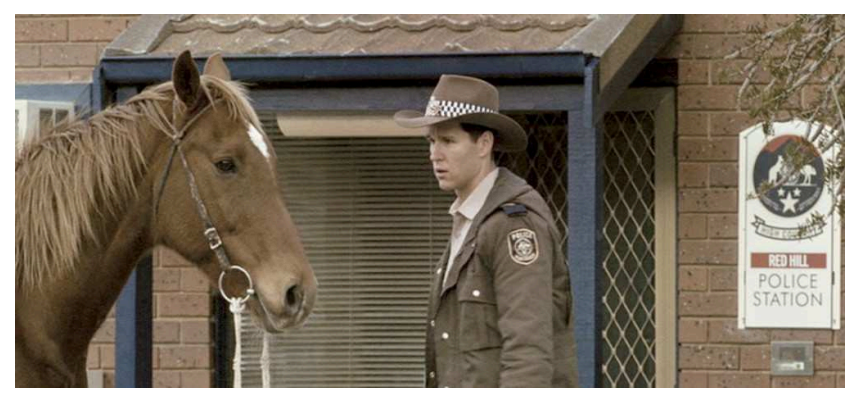

Fig. 5

The moments of passivity and gentleness allow particular meanings about the relationship between truth and fiction to be generated by this film, that would not be possible in a straightforward, gratuitous revenge narrative. The highly stylised mise-en-scene, for instance, creates an interesting dialectic that blurs the boundaries between the historical fact and cinematic imaginings. Although Red Hill uses Western genre tropes, it does not do so with the intention of reconstructing a realistic Australian frontier. Rather, classic Hollywood Western signifiers are used in a modern day setting: alongside the wide-open lands are bitumen roads; some men ride horses, others drive cars; the police uniforms are contemporary; and information is communicated via television, radio and mobile phones. The only "traditional" Aborigine in the film is a 
plastic one on display at the town's information centre. A postmodern hyperreality results, a simulacrum which, as per Baudrillard, effectively "threatens the difference between the 'true' and the 'false'. The 'real' and the 'imaginary"' (3). Modern characters "playing" the Western frontier at a different time in Australia's history open up the possibilities of signification. The surety of past realities and present-day circumstances are all called into question.

A mythical black panther-rumoured to be roaming Red Hill at the same time as Conway is wreaking havoc-makes drawing any truths from this narrative even more elusive. According to Gleeson (Cliff Ellen), legend has it that the panther is in the area as a result of its forbears' escape from a circus in the 1800s. Similar myths circulate in Australian rural legend, so much so that Julie Rigg refers to this as a "well entrenched Australian rural myth". Some reviewers interpret the panther as a metaphor for a mystical indigenous presence in the outback. For example, Simon Foster writes: "a strange sequence involving the appearance of a mythological panther, whilst dreamily effective, both overstates and convolutes Jimmy's connection to the land" and another review states: "The symbolism of this mysterious black beast gives the film an almost otherworldly mysticism, representing an omnipotent dark justice that watches over the land" (Buckmaster). However, as Old Bill rightly points out, "This is Australia, not bloody Africa" and the panther is a disconcerting image in the Australian outback. It does not overstate Jimmy's connection to the land, as Foster suggests, but rather it complicates the picture of just who and what belongs in the Australian space. The closing credits are interrupted by a shot of the animated panther overlooking the land from on high, suggesting that Gleeson, and not Old Bill, was right. Mythology certainly looms large in Red Hill, and rather than confirming one truth or another it instead creates an undermining state of hyperreality.

Red Hill also attempts to collapse the truth/ reality dichotomy from the reverse approach. Into the hyperreality that is created by the stylised mise-enscene and wandering Disney-style beast is the film inserts an entirely realistic race-based premise for revenge. Towards the end of the film Cooper discovers, via Gleeson, that Conway had objected to a railway line being built to the town because it would interfere with a sacred Aboriginal burial site. As revenge for obstructing a piece of infrastructure that was considered muchneeded, Old Bill and his cronies took Jimmy's pregnant wife, raped and killed her, burned down his house, and accused him of the murder. Contemporary viewers will be familiar with Conway's cause; Aboriginal sacred areas are often found to be obstructing urban expansion. The film calls to mind the very public Hindmarsh Island Affair in the 1990s, for example, and at the time of Red Hill's release Tasmanian Aborigines were protesting the development of a bridge over the Jordan River Levee for fear it would damage a significant Aboriginal site ("Jordan River").

This realistic premise, however, triggers highly unrealistic reactions by the men of Red Hill, and, when combined with the comic-book feel of the film, means little interest in a single truth of Australian frontier relations is demonstrated. Too unreal to be a threat, perhaps, this film has attracted none of the criticism afforded The Tracker with regards to veracity. Lydon's argument about the distancing effect of stylised cinematic that she applies to The Tracker applies most readily to Red Hill-the simple shopfronts and postmodern pastiche, for example, leave no doubt that it is fictive.

Red Hill also is permeated by the longing for the triumph of good over evil that drives The Tracker. The evils of pre-Cooper Red Hill are abolished soon after his arrival. There are concerns amongst the locals of Red Hill that the town is stuck in the past and as a consequence is dying. Cooper walks past empty shops on his way into town, and an early scene depicts a meeting in the Town Hall at which concerned locals discuss ways to bring life to the town. One local, Martha, states: "Instead of living in the past this town ought to be looking toward new revenue streams." Old Bill represents the opposing view and, addressing the crowd in a booming voice, states: "Our forefathers didn't sacrifice their blood sweat and tears so a bunch of wankers can come here and sip fucking pinot." Cooper, the "city boy," is symbolic of the change that Red Hill is anticipating. Via Old Bill the past is aligned with ignorance and racism, and the 
old and their outdated attitudes are on the way out in this film. Old Bill claims to own the town, and make the rules. However his days of wielding power are over by the close of the film. When just before his death he yells at Cooper: "You're not the law in this town, this is my town, my town!" the spectator knows that this is no longer the case. Old Bill has been replaced with a new breed of policeman, and all the evil townsfolk have been obliterated. Like in The Tracker, bigotry does not survive on this cinematic frontier.

As such, we are left with the feeling that the only future for Red Hill is pro-reconciliatory. Cooper and Conway are allied from the beginning of the film. They are at odds with the old guard police and both represent the morally right side of the conflict. Conway, for example, is respectful of Cooper's pacifism. When Cooper lays down his gun on first meeting Conway, opting for reason over violence, his life is spared in return. The film employs poignant close ups of Conway and Cooper to encourage a sense of knowing and understanding between the two. Significantly, the only words that Conway speaks at the end of the film establish a connection between himself and Cooperhis wife was also having a boy (figure 6). Jimmy then dies in a Christ-like position, arms outstretched as he falls dramatically to the ground. His resurrection comes through Cooper's son, a replacement for his own, and as such, a highly symbolic message of hope for a reconciled nation.

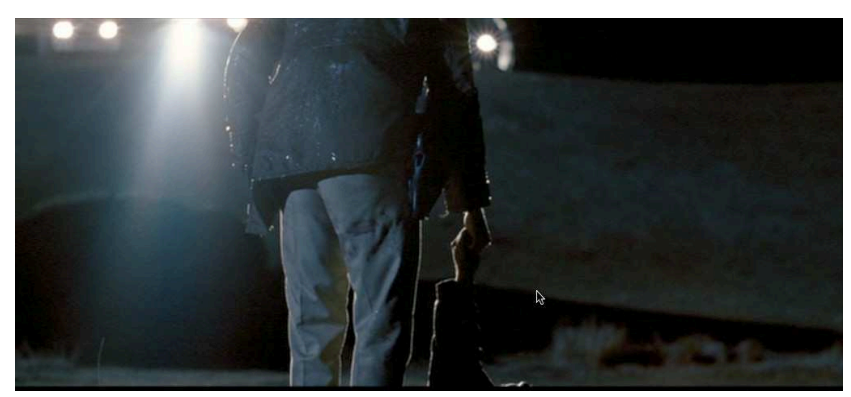

Fig. 6

\section{Conclusion}

These postcolonial Westerns are enmeshed with debates about history telling, truth and the relationship of the past with the present. The Tracker and Red Hill contribute directly to debates also about the extent to which the construction of convoluted and intricate pasts bears directly on the here-and-now. They imagine the Australian frontier as a place where racial violence, hatred and ugliness were, if not matched, then at least partially counter balanced by non-violence, love and beauty. Amid the cruelty and brutality is also a contesting nostalgic sense of camaraderie and cross-cultural understanding. The Western provides opportunity for violence and nostalgia to co-exist onscreen. Whilst not typical Westerns, neither are these typical Australian nostalgia films either, as defined by O'Regan as films common to the mid-1970s to mid-1980s which were concerned with aesthetics and atmosphere and the avoidance of conflict (197) (for example, Breaker Morant, Caddie, Picnic at Hanging Rock and My Brilliant Career). They are nonetheless looking back in an atmosphere, and with aesthetics, that generate a sense of longing even if for only the slightest hint of a rosier past.

The characters in these films, black and white, are capable of terrible brutality and gentle sensitivity. No single frontier truth emerges from these films. Rather, they contribute to a range of memories, stories and scholarly work that constitutes Australian colonial history. They explore alternatives to the traditional colonial dichotomy of the powerful police and the Aboriginal victims. In The Tracker subversiveness and power comprise the ambiguous tracker figure, who ultimately outsmarts the seemingly all-powerful policeman. In Red Hill the racist, murdering police are replaced by the representative of a new breed, knowledgeable and sensitive officers who seek to right past injustices committed against Aboriginal people. These representations of settler-indigenous relations between police, troopers and outlaws lead to a picture of the frontier as a place of multifarious possibilities for cross-cultural relations.

Similarly, both films are beautiful in ways that complicate the depictions of brutality. In The Tracker close ups, slow motion and a poetic soundtrack soften the racial violence, and Red Hill displays a gentleness and sensitivity between Cooper and his wife that is in 
sharp contrast to the violent rape of Conway's pregnant wife. What results is not one simple version of early colonisation, but multiple perspectives highlighting the ambivalences of history, its breadth of possible meanings and the multi-layered subjectivities of its inhabitants, black and white. Attwood articles the importance of this when he writes:

In much of the telling of the stolen generations narrative, the attacks upon it, and the enormous debate that has followed, simplistic histories of colonialism in Australia have been advanced. This has severely limited the prospects for historical understanding among and between Aboriginal and non-Aboriginal Australians, and has undermined an opportunity for bringing about change. ("Learning" 184)

These films circumvent not only the construction of the Australian frontier as a place of simple incessant violence without suggesting it was an idyllic haven. In doing so they construct a convoluted frontier and the possibilities for more nuanced understandings of both the past and the present.

Screening the past is, by necessity, a contemporary engagement with events, issues and ideologies of precedingeras. The Tracker and Red Hilleach use presentday musicians and modern cinematic techniques to remind the viewer that these films are expressions of contemporary knowledges and sensibilities. Despite concerns about the limitations of fiction's ability to engender serious viewer engagement with the issues at stake in the films, this article demonstrates that a fictive exploration of the past, which reveals the nuances and ambivalences of historical cross-cultural relations, does not only re-vision that past but also re-configures the possibilities for the present. Adrian Martin considers that a nuanced interpretation means that any potentially conflicting (in this case, frontier) values are viewed, "not as a contest (victor take all), but rather as an uneasy but dynamic truce, a hybrid formation of the past and present, forever changing places between living and dead, nature and culture" (26) and suggests this provides an ideal forum for a debate about reconciliation (27). This article highlights how the re-visioning of the past in The Tracker and Red Hill does just that. Each bespeaks a desire to rework the past with an ear to contemporary tussles over reconciliation. The postcolonial longing in these two films hears the echoes of intricate and contesting camaraderie between settlers and indigenes past, whilst anchoring their narratives firmly in the present. The Tracker and Red Hill generate as much hope for settler-indigenous relations as they do despair over past events: that which is desired is desired of both past and present.

\section{Notes}

1. The Tracker has also been described as an antiwestern (along with the 2005 film The Proposition by Director John Hillcoat), and Red Hill as neo-western (Buckmaster, "Red Hill"). For a fuller discussion about the difficulties around classifying these and other Australian films as westerns see Bruno Starrs's "Two Westerns that Weren't" and Brian McFarlane's "Brokeback and Outback."

2. Thanks to Rolf De Heer and Patrick Hughes (The Tracker and Red Hill respectively) for permission to reproduce the images contained in this article.

\section{References}

Attwood, Bain. "Learning About the Truth': The Stolen Generations Narrative." Telling Stories. Ed. Bain Attwood and Fiona Macgowan. Crows Nest: Allen and Unwin, 2001. 183-212. Print.

Telling the Truth about Aboriginal History. Crows Nest: Allen and Unwin, 2005. Print.

Attwood, Bain, and Dipesh Chakrabarty. "Risky Histories." Meanjin 65.1 (2006): 200-07. Print.

Berg, Olaf. "The Challenge of Film Considered as Historical Research" Cultural Studies Review 14.1 (2008): 124-136. Print.

Bhabha, Homi. The Location of Culture. London and New York: Routledge, 1994. Print.

Baudrillard, Jean. Simulacra and Simulation. Trans. Sheila Faria Glaser. Ann Arbor: U of Michigan P, 1994. Print.

Buckmaster, Luke. "Red Hill Movie Review: Ferocious Neo-Western Australiana." Cinetology, 28 Nov. 2010. Web. 8 Jan. 2011.

Burgoyne, Robert. The Historical Hollywood Film. Oxford: Blackwell Publishing, 2008. Print. 
The Chant of Jimmy Blacksmith. Dir. Fred Schepisi. Perf. Tom E. Lewis et al. Umbrella Entertainment, 1978. DVD.

Clarke, Cath. "Red Hill: Review." Guardian UK 29 May 2011. Web. 12 June 2011.

Clendinnen, Inga. "True Stories and What We Make of Them." Essays on Australian Reconciliation. Ed. Michelle Grattan. Melbourne: Black Inc, 2000. 242-53. Print.

Collins, Felicity, and Therese Davis. Australian Cinema After Mabo. Cambridge: Cambridge UP, 2004. Print.

Davis, Natalie Zemon Slaves on Screen: Film and Historical Vision. Massachusetts: Harvard UP, 2000. Print.

Elley, Derek. "Red Hill." Variety 15 Feb (2010). Web. 17 June 2010.

Ferrero-Regis, Tiziana. "Imagining Australia: Landscape and Place in Indigenous Films after Mabo." Placing the Moving Image. Ed. Tiziana Ferrero-Regis and Albert Moran. Brisbane: Griffith University, 2004. 89-107. Print.

Foster, Simon. "Weak Script Blunts Brutal Outback Western." SBS Film 2010. Web. 18 August 2012.

French, Philip. "Red Hill: Review." The Observer 15 May (2011). Web. 24 May 2012.

A Frontier Conversation. Dir. Claire Haywood. Ronin Films, 2006. Video.

George, Sandy. “(Re)writing History." Storyline 24 (2008): 20-22. Print.

Gillard, Garry. "The Tracker: More than the Sum of its Types." Australian Screen Education 34 (2004): 115-19. Print.

Grindon, Leger. Shadows on the Past. Philadelphia: Temple UP, 1994. Print.

Habermas, Jurgen. Truth and Justification. Trans. Barbara Fultner. Cambridge: The MIT Press, 2005. Print.

Hayward, Susan. Cinema Studies: The Key Concepts. 3rd ed. New York, Oxon: Routledge, 2006. Print.

Jacobs, Naomi. The Character of Truth: Historical Figures in Contemporary Fiction. Carbondale and Edwardsville: Southern Illinois UP, 1990. Print.

Jones, Philip. Ochre and Rust. Kent Town: Wakefield, 2007. Print.

"Jordan River Levee, Southern Tasmania, Site of Massive Aboriginal Artefact Find." ABC News. 10 August 2011. Web. 19 July 2012.

Journey Out of Darkness. Dir. James Trainor. Perf. Konrad Matthai et al. British Empire Films and National Film and Sound Archive, 1967. DVD.

Kiss, Elizabeth. "Moral Ambitions Within and Beyond Political Constraints: Reflections on Restorative Justice." Truth v. Justice. Ed. Robert I. Rotberg and Dennis Thompson. Princeton: Princeton UP, 2000. 68-98. Print.
Langton, Marcia. “Out From the Shadows." Meanjin 65.1 (2006): 55-64. Print.

Lydon, Jane. "A Strange Time Machine: The Tracker, Black and White and Rabbit-Proof Fence." Australian Historical Studies 35.123 (2004): 137-48. Print.

Maddison, Sarah. Black Politics. Crows Nest: Allen and Unwin, 2009. Print.

Martin, Adrian. "On the Level: The Dark Side of Australian Cinema in Wolf Creek and The Proposition." Photofile 76 (2005): 26-27. Print.

McFarlane, Brian. "Back Tracking." Meanjin 62.1 (2003): 59-68. Print.

. "Brokeback and Outback." Meanjin 65.1 (2006): 65-71. Print.

O'Regan, Tom. Australian National Cinema. London and New York: Routledge, 1996. Print.

Owens, Jared. "Film-makers Dispatch Windschuttle to the Fence." The Australian 15 December 2009. sec. The Nation: 7. Print.

Perpitch, Nicolas. "Rabbit Claims a Distortion, says Author." The Australian 14 Dec. 2009, sec. The Nation: 7. Print.

Probyn, Fiona. "An Ethics of Following and the No Road Film: Trackers, Followers and Fanatics." Australian Humanities Review 37 (2005). Web. 18 Feb 2010.

The Proposition. Dir. John Hillcoat. Perf. David Gulpilil et al. Becker Group, 2005. DVD.

Rabbit-Proof Fence. Dir. Phillip Noyce. Perf. David Gulpilil and Everlyn Sampi. Hanway Films, 2002. DVD.

Red Hill. Dir. Patrick Hughes. Perf. Ryan Kwanten, Steve Bisley and Tom E. Lewis. Sony, 2010. DVD.

Reynolds, Henry. The Chant of Jimmy Blacksmith. Sydney: Currency, 2008. Print.

This Whispering in Our Hearts. St Leonards: Allen and Unwin, 1998. Print.

Ridgeway, Aden. "An Impasse or a Relationship in the Making?" Essays on Australian Reconciliation. Ed. Michelle Grattan. Melbourne: Black Inc, 2000. 12-17. Print.

Rigg, Julie. "Red Hill." MovieTime, ABC Radio National. 26 Nov. 2010. Podcast. 20 Mar. 2012.

Rosenstone, Robert, A. "The Historical Film as Real History" FilmHistoria 5:1 (1995): 5-23. Print.

Sansom, Basil. "The Brief Reach of History and the Limitation of Recall in Traditional Aboriginal Societies and Cultures." Oceania 76 (2006): 150-72. Print.

Shaw, David. Gerald Massey: Chartist, Poet, Radical and Freethinker. lulu.com. UK, 2009. ebook. 15 Dec. 2009.

Smaill, Belinda. “The Tracker." Metro 134 (2002): 30-33. Print. 
Starrs, D. Bruno. “Two Westerns that Weren't: The Tracker and The Proposition." Metro 153 (2007): 166-72. Print.

Sutton, Peter. The Politics of Suffering. Melbourne: Melbourne UP, 2009. Print.

The Tracker. Dir. Rolf de Heer. Perf. Damon Gameau et al. The Globe Film, 2001. DVD.

Windschuttle, Keith. "The Myths of Frontier Massacres in Australian History." Quadrant 44.12 (2000): 6-20. Print.

Recebido em: 23/02/2016

Aceito em: 06/04/2016 